\title{
RIZAL AND THE MOTHER OF ALL INSURGENCIES
}

\author{
E. San Juan, Jr. \\ Philippine Cultural Studies Center \\ philcsc@sbcglobal.net
}

\begin{abstract}
A new appraisal of Rizal is needed today in the light of 9/11, the collapse of finance capital, state terrorism, and neoliberal decadence and barbarism. Rizal's revolutionary critique can be discovered by shifting the center of inquiry to the Dapitan years and after, the Liga's resonance, and the Sisa-Maria Clara-Salome nexus. By exposing the limits of Simoun's romantic idealism, Padre Florentino's eschatological impulse, and the carnivalesque colonial world bereft of god/nomos, Rizal anticipates the post-capitalist predicament. Women's vengeance against patriarchal nihilism lies submerged in Rizal's communicative action to the Malolos collective, mobilizing emergent and residual historical forces in a dialectical trajectory of canceling the negative (mystifying ideologies and practices) and salvaging the mother's body/place for transformative re-incarnations. This seismograph of changes in his situation (after the utopian scheme of founding a new Calamba in British Borneo) serves as the enabling fountainhead of Rizal's theory of transforming patria, the mother of all insurgencies. Rizal's nationalism prefigures the third-world revolutionary projects of Fanon, Ho Chi Minh, Mao, Che Guevara, Amado V. Hernandez, and the national-democratic activists of our time.

Keywords

babaylan, Filipino woman, manggagaway, Rizal's novels, Rizal's women characters

About the author

E. San Juan, Jr. was recently a fellow of the W.E.B. Du Bois Institute, Harvard University. He is emeritus professor of English, Comparative Literature, and Ethnic Studies from various US universities. He served as Fulbright professor of American Studies at Leuven University, Belgium; visiting professor of Comparative Literature at the University of the Phlippines; and fellow at the Rockefeller Study Center in Bellagio, Italy. Among his recent books are Balikbayang Sinta: An E. San Juan Reader (Ateneo de Manila UP), Rizal in Our Time (revised ed. Anvil), and US Imperialism and Revolution in the Philippines (Palgrave).
\end{abstract}

Liberty is a woman who grants her favors only to the brave. Enslaved peoples have to suffer much to win her, and those who abuse her lose her... Les femmes de mon pays me plaisent beaucoup, je ne mk'en sois la cause, mais je trouve chez-elles un je ne sois quoi qui me charme et me fait rever [The women of my country please me very much. I do not know why, but I find in them I know not what charms me and makes me dream.]

- Jose Rizal, Epistolario Rizalino;

Diary, Madrid, 31 March 1884 
Religious misery is at once the expression of real misery and a protest against that real misery. Religion is the sign of the hard-pressed creature, the heart of a heartless world, the spirit of unspiritual conditions. It is the opium of the people.... After the earthly family is discovered to be the secret of the holy family, the former must then itself be criticized in theory and revolutionized in practice.

- Karl Marx, "Introduction to the Critique of Hegel's Philosophy of Right" (1843) and

“Theses on Feuerbach" (1845)

In the now classic treatise, The Origin of the Family, Private Property and the State, Friedrich Engels formulated the cardinal insight that the inequality of the sexes coincided with the rise of class society: "The overthrow of mother right was the world-historical defeat of the female sex" (120). Within the patriarchal monogamous family based on private property (land, domesticated animals, slaves), Engels added, "the woman was degraded and reduced to servitude; she became the slave of his lust and a mere instrument for the production of children" (120-21). Women were relegated to the private sphere of the kitchen and boudoir under male authority. Historically, the form of patriarchal supremacy is a result of the class contradictions prevailing at a particular stage of social development, from savagery to slave, feudal, and capitalist stages. The anthropologist Robert Briffault noted that with the institutionalization of monogamous marriage and the nuclear family as the basic economic unit, the supremacy of the male became normative; the male head of household production with property-holding rights and the privilege of disposing surplus wealth displaced the mother. Structural coercion based on the male's inalienable right to property defined women's differential access to resources and their unequal life-chances. Integrally central in maintaining early tribal communal relationships, women lost their equal share in productive tasks and with it that acephalous solidarity gutted by "the rise of competitive interests," by commodity fetishism and the cash-nexus (Hays 179-80; Caudwell). With the onset of capitalism, males became the bourgeois masters, women the proletarian class within the family.

\section{REVISITING THE MATRIX}

In pre-Hispanic Philippines, residual mother-right flourished within extended kinship groups (gens or clans) engaged in hunting, fishing, and subsistence farming in communally managed territory. Production was chiefly for use, not for exchange. In those self-provisioning communities, there was no substantial surplus; women inherited property and exercised a large 
degree of autonomy. Women's productive function in gathering food, fishing, planting/harvesting, domestic and artisanal crafts (weaving, pottery, etc.) gave them economic independence and parity with men. In reviewing the status of native women before and after the conquest, Elizabeth Eviota observes that women producers controlled their own labor and its fruits, while "unmarried women exercised their sexuality freely ... Women were the valued people exchanged in the marriage transaction" supervised by kins and the whole community (35-36). Women's active role in production and reproduction allowed them to be relatively sovereign thinking, enjoying subjects endowed like men with the human-species potential actualizable through cooperative sensuous praxis.

Spanish colonialism destroyed that egalitarian communal setup. It ushered a thoroughgoing gender differentiation with the institutionalization of private property, monogamy, and the patriarchal authority of fathers within the family. The cloistering of women within the maledominated household limited them mainly to accomplishing religious and household duties. Onerous tribute of unpaid labor reduced the natives to debt peonage, the root of the iniquituous patron-client tie-up that legitimizes inequality across race, class, and gender. With the church regulating women's bodies/sexuality and imposing a regime of chastity, women displaced from work and driven to prostitution or vagrancy were confined to convents and public jails, or deported to Palawan. Rizal depicted the methodical surveillance of women (chiefly via the confession as the disciplinary, therapeutic technique) in the plight of Doña Victorina, Doña Consolacion, Maria Clara, Sisa, Juli, Paulita Gomez, among others. Eviota concludes: "Centuries of economic, political, and religious imposition had transformed the lively sexual assertiveness of Filipino women into a more prudish, cautious image of womanhood" (61). The church-sanctioned institutions of monogamous marriage and the colonial State's routinization of charisma (Gurvitch) sealed the final demise of "mother-right," with the babaylans reduced to witches or malignant brujas. The fate of Maria Clara encapsulates the loss of status of women of the emerging principalia, and of the more intense pacification of her lesser sisters in the symbolic-ideological template of a racialized patriarchal society. Nonetheless, those who refused marriage or violated/resisted the despotic family - Ibarra, Elias, Salome, Basilio, Tasio, Cabesang Tales, and others - presaged a salvific and reconciling utopian future for all since the social contract depended on unchallenged male ascendancy.

Within this historical-materialist framework, we can properly appreciate Rizal's works as articulations of a synthesizing theoretical inquiry in which the form of universality springs from the concrete singularity of particular lifeworlds (Oizerman). Social totality acquires concrete dynamics in the lived experience of sensuous reflective subjects. Aesthetically, they render typical what are specific and individual. The predicament of Maria Clara, Sisa, Salome, Juli, Doña Consolacion and other characters in Rizal's novels becomes emblematic of the decaying colonial order of 
nineteenth-century Philippines. In depicting the physiognomies and symptomatic acts of his female protagonists, Rizal also presented a lucid anatomy of the body politic, the diseased corpus for which he was imploring his audience to suggest a cure. In short, the key to understanding Rizal's revolutionary critique of colonial society may be found in his realistic-allegorical delineation of women in his fiction and discourse. By symbolic extrapolation, Rizal shows how patriarchal supremacy founded on the control of women's bodies and their productivity becomes the ultimate "weak link" in the colonial class/race hierarchy the toxic vestiges of which still afflict us today (epitomized among others by the Catholic Bishops' opposition to the Comprehensive Reproductive Rights Bill [HB 4244] being proposed in the Philippine Congress).

\section{ORTHODOX/HETERODOX ENUNCIATIONS}

In a much anthologized essay "The Filipino Woman" written at the height of the Cold War, Carmen Guerrero Nakpil elaborated a notion of the Filipino woman as a heterogeneous, multifaceted, amphibious creature that seems to inhabit not those tropical islands in Southeast Asia but some kaleidoscopic realm of fantasy. Not that she defied history or geography; in fact, she dared to encompass both by presenting a hybrid, polychromatic portrait. It is a sophisticated attempt to capture the variegated position of Filipino women in history, offering us a pretext to explore Rizal's thinking about women, sexuality, gender, and everyday life in the context of anticolonial resistance. If prisons, for Dostoevsky, index the truthful condition of any society, then the situation of women may be considered the revealing symptom of the health or malaise of their habitat, both its sociohistorical and psychic configuration.

Nakpil is a liberal but dilettantish observer of Filipino manners and mentalities. She is careful to discriminate fact from fiction: "Although, historically, it would be inaccurate to go so far as to maintain, as many writers like Rizal and Craig have, that amazonian princesses like Urduja and autocratic matriarchs like Sima once ruled over Filipinos ... [what] these pretty tales of displaced queens seek to symbolize was nonetheless solid and substantial reality." The truth, however, involved a more elaborate, complex interweaving of hierarchical gender-differentiated and autonomous spheres (Eviota). After the Spaniards converted the indigenous barangays and made the Filipina "preoccupied with fig leaves," Rizal and his nineteenth century contemporaries had to go to Europe "to get a good look at women." Rizal's women were classified legally by the Spanish regime together with infants and idiots, Nakpil adds, "for she could neither enter into contracts without her husband's consent, if married, nor leave her home without her parents' consent before 25, if unmarried." That applies of course to upper-class women. She concludes that the Filipino woman of the period just after World War II is "a sort of compromise between the 
affected little Christian idealist of the Spanish regime, the self-confident go-getter of the American era, and the pagan naturalist of her Asiatic ancestors" (14). From this mixture of lifestyles and essentialized ingredients, Nakpil supposes that in a few generations, the Filipino woman will iron out her "mongrel contradictions" into a "thoroughbred homogeneity" embodied in a "clear, pure, internally calm, symmetrical personality." But she resists such a possibility. Why? Because then she "will have lost the infinite unexpectedness, the abrupt contrariness, the plural unpredictability which now make her both so womanly and so Filipino" (18). Ludic postmodernism takes over empirical realism.

We thus confront a creature both womanly and Filipino despite circumstances and contingencies. But is this gendered construct real or imagined? In the midst of the rancorous debate over the Reproductive Health Bill, we wonder whether Nakpil's image of the polymorphously perverse, composite Filipina body is causing all the furor and controversy. Is this aleatory, contrarious, unpredictable group the pretext, topic, occasion, or effect of what is happening? As the comparatist anthropologist Jack Goody has demonstrated, the historical status of women in any society depends on the nuanced articulation of the family, cultural specifics, and the politicoeconomic system, in which a degree of structural autonomy may exist between production and reproduction: patriarchal authority in politics, matrilineal power in the domestic domain, and various permutations of kinship and sexual division of labor (95).

An analogous controversy bedevils the position of women in Rizal's discourse which makes problematic their catalyzing or counter-bewitching resonance in his life (more on witches later). This is not virginal territory to explore. All the Rizal biographies cannot avoid mentioning, if not belaboring, the propaedeutic influence of his mother Tedora Alonso, Leonor Rivera, and Josephine Bracken, not to forget the shadowy Segunda Katigbak and the vibrant Nelly Boustead hovering over the margins of his memoirs. But from this distance in time and space, it is self-indulgent to speculate on the erotic, libidinal adventures of the hero-unless we intend to package that aura of romantic melodrama for sale to the profit-maximizing mass media. Are we not reeling from a surfeit of these banalities and trivia? For our purpose of doing an experiment in thought/critique about the function of the female/feminine in Rizal's thought and its reverberations in ideological struggle, this essay will be limited to a focus on one question: Was Rizal (his life and works) a contributor to the maintenance of the patriarchal order or a critic of the effects of the social division of labor in class society, which is the condition of possibility for male supremacy, sexist chauvinism, and the exploitation and oppression of women? Are characters such as Sisa, Maria Clara, Salome, and Juli significant for more than their technical efficacy in the melodramatic twists of the narrative? What ultimately is the role of Josephine Bracken in the sequence of women-protagonists in Rizal's life beginning with, say, Segunda Katigbak? What follows are speculative glosses and 
heuristic reflections, a cognitive mapping of the subject-position of this "Other" whose subliminal tracks were already outlined by Nakpil's versatile pen.

\section{SYNDROME OF THE IDEAL}

Most discussions of Rizal's women usually start with Maria Clara and her counterpart in real life, Leonor Rivera. Let us not tarry with the first whose value as a model was fully assayed first by Salvador P. Lopez in his "Maria Clara-Paragon or Caricature?" in Literature and Society, and put to rest in the trenchant critical inventory of Dolores Feria's "The Insurrecta and the Colegiala." Of the informed Rizal commentators, only Nick Joaquin seems to be scandalous enough to salvage Maria Clara from the Victorian cesspool. Joaquin urges us to read again Chapter 7, "Idyll in an Azotea," and pay close attention to the eyes of Maria Clara and Juan Crisostomo Ibarra, for "the question that love poses in a bright or veiled glance cannot be answered by speech" (11). But the encounter between the two lovers is not just optical; it is noisy, as it were, counterpointed by a plethora of ventriloquizing voices, not a conversation but spliced whispers of two solitary persons communing with conscience and gnomic spectral presences.

What is curious is that face to face with his beloved, Ibarra invokes the organ of memory where Maria Clara's image blends with the landscape of his journeys in Europe mixed with local scenery. Remembrance resurrects the past: "[your memory] has been my comfort in the solitude of my soul in foreign countries; your memory has negated the effect of the European lotus of forgetfulness, which effaces from the remembrance of our countrymen the hopes and the sorrows of the Motherland." For the traveling native, the beloved has metamorphosed into "the nymph, the spirit, the poetic incarnation of my country: lovely, simple, amiable, full of candor, daughter of the Philippines, of this beautiful country which unites with the great virtues of Mother Spain the lovely qualities of a young nation" (Rizal, Noli 58). For the expatriate fabulist, the local muse Maria Makiling is just around the corner.

Idealization sanitizes the submerged furies of envy and jealousy. Amidst this elaborate rhetoric of denying that Ibarra has forgotten her sweetheart, the past returns in the farewell letter he wrote, which she reads to remind him of "pleasant quibbles, alibis of a bad debtor." The demure, acquiescent paramour revives the admonishing tone of Ibarra's father, with a message recalling the mother's death and the father's impending demise, and the need to sacrifice the present for a "useful tomorrow for you and your country." This patriarchal command, transmitted through the son's fiancee, agitates Ibarra and compels this retort: "You have made me forget that I have my duties" to honor the dead. Agreed, Maria Clara was not "a namby-pamby Manang," as Joaquin chides us; and that her confessor found her a problem girl. Nonetheless, she is only a mediating 
instrument for Ibarra to satisfy the traditional demands of filial piety and vindicate the honor of the ancestral totems. In the end, she is used by Padre Damaso (her biological father) to humiliate Ibarra by forcing the cuckold Capitan Tiago to marry her to another man, Linares.

Residual matrilineality soon asserts itself. When Ibarra returns after his escape from the guardia civil to see Maria Clara for the last time, he renews his vow by figuratively restoring the power of mother-right: "By my dead mother's coffin, I swore to make you happy no matter what happened to me. You could break your own pledge, she was not your mother, but I who am her son, I hold her memory sacred and despite a thousand perils, I have come here to fulfill my pledge" (532). For her part, Maria Clara reveals the secret of her origin - the friar's violation of Capitan Tiago's trust and her mother Pia Alba, the break-up of the illusion of the Indio father's authority - and her promise not to forget her oath of fidelity. The inscrutable becomes legible by oral mediation. This scene follows Elias' renunciation of the patriarchal mandate to uphold the tarnished family honor by refusing to take revenge on Ibarra and allow the unity of all the victims seeking justice to supersede his clan's particularistic interest. Nonetheless, Maria Clara serves throughout as the seductive screen of the fathers and the dutiful sons.

\section{WITNESS TO EMERGENCIES}

By the time Rizal was born in 1861, the predominantly feudal/tributary mode of production was already moribund and an obstacle to further socioeconomic development. Trade and commerce expanded when the country was opened to foreign shipping in 1834-1865, especially after the completion of the Suez Canal in 1869 (Arcilla). Vestiges of courtly love and chivalric ways dissolved in the triumph of the cash-nexus warranted by merchant and circulation capital, further validating profitable marital exchanges to expand or consolidate property. A national market arose. While the islands for the most part remained tribal and rural under the grip of the rent-collecting frailocracy and its subaltern principalia, land-tilling families such as those of Rizal flourished within the limits of the colonial order. The family household organization enabled the socially constructed gender asymmetry based on biological difference to segregate daughters from sons (women assigned to procreation and child nurturance, men to public affairs) and adversely affect their potential to develop as creative human beings and morally responsible citizens.

Political power continued to be monopolized by the peninsulars in the bureaucracy and military, together with the religious orders. They controlled large estates and appropriated the social wealth (surplus value or profit) produced by the majority population of workers and peasants most of whom were coerced under law (for example, the polo servicios) and reduced to slavish penury. Ruthless pauperization also doomed indigenous folk deprived of access to public 
lands, animals, craft tools, and so on. Only a tiny minority of Creoles and children of mixed marriages (mestizos of Chinese descent) were allowed to prosper under precarious, serf-like, and often humiliating conditions that eventually drove them to covert or open rebellion. Rizal was one of these children sprung from the conjuncture of contradictory modes of production and reproduction of social relations, a child responding to the sharpening crisis of the moribund, decadent Spanish empire.

Rizal's family belonged to the principalia, the town aristocracy. His parents owned a large sumptuous stone house and adjacent property; their wealth derived from cultivating leased land owned by the Dominican Order which later expelled them for refusal to accede to a rental increase and other impositions. Rizal's mother managed a store and operated a flour-mill and ham press; the parents traced their lineage to merchants and provincial officials with affluent Chinese petty-bourgeois provenance (see Chapters 2-4 in Craig). With a private library of more than 1,000 volumes (the largest in Calamba, Laguna), the Rizals (of eleven children, nine were women) enjoyed a relatively privileged rank among the native gentes or clan establishment. Compared to his muted respect for his father, Rizal esteemed his "clairvoyant" mother in a more expressive and exuberant way: "My mother is a woman of more than ordinary culture; she knows literature and speaks Spanish better than I. She corrected my poems and gave me good advice when I was studying rhetoric. She is a mathematician and has read many books" ("Rizal to Bluementritt" 335). Intellectually more adept than her husband and belonging to a more distinguished clan of professionals, Teodora Alonso (Rizal complained in the same letter to Blumentritt) "did not want that I should study more!"

Later on, in an 1884 letter copied by Leonor Rivera, Rizal's mother would advise him not to "meddle in things that will distress me," congratulating him on his graduation: "I'm thanking our Lord for having bestowed on you an intelligence surpassing that of others" (Letters 159). But she wryly cautions him not to be too wise: "If he gets to know more, the Spaniards will cut off his head." Confident and proud of his accomplishments at the Ateneo and in Europe, Rizal set the warning aside. No doubt Rizal worshipped his mother; consequently, when she was subjected by Calamba's gobernadorcillo and guardia civiles to the cruel punishment of walking from Calamba to Santa Cruz, a distance of 50 kilometers, on a charge that was never substantiated, Rizal suffered an incalculably profound trauma. It was a deeply painful wound that disturbed him enough to motivate him to condemn-to quote his rationale for writing his novels - "our culpable and shameful complacence with existing miseries," and "to wake from slumber the spirit of the Fatherland." The mother's ordeal served as the primal scenario of violation, the initiation into the crucible of Rizal's life-pilgrimage. It also marked the defeat of the Indio fathers - their virtual emasculation and castration - and the return of the avenging Furies of classical natural law. 
Rizal was then only eleven years old when his mother was arrested on that malicious charge. She and her brother Jose Alberto, a rich Biñan ilustrado, were accused of trying to poison the latter's wife who abandoned his home and children when the husband was on a business trip in Europe. It was Teodora Alonso who persuaded the brother to forgive his wife's infidelity, to no avail; the wife connived with the Spanish lieutenant of the Guardia Civil to file a case in court accusing her husband and Doña Teodora of trying to kill her. Rizal's recounting of the disaster (in the Memorias entry from Jan. 1871 to June 1872) does not wholly capture the devastating impact of this disaster on the adolescent's psyche: “The mayor ... treated my mother with contumely, not to say brutality, afterward forcing her to admit what they wanted her to admit, promising that she would be set free and re-united with her children if she said what they wanted her to say.... My mother was like all mothers: deceived and terrorized" (The Young Rizal 30). Rizal visited her in prison; she endured the unjust imprisonment for two years and half. With his brother also suspected of complicity with Father Jose Burgos, executed with Fr. Gomez and Fr. Zamora for sedition, Rizal summed up the effect of the two events: "From then on, while still a child, I lost confidence in friendship and mistrusted my fellowmen." Leon Maria Guerrero rightly appraised this unbearable tragedy of his mother as the key pivotal experience that Rizal could not face except through the anonymous student diary we quoted. He grappled with it through the cathexis of a public grievance, the 1872 martyrdom of the three secular priests which tormented his brother Paciano, "not so agonizing or so personal as his beloved mother's shame ... shamefully imprisoned, unfairly tried and unjustly condemned" (Guerrero 17; Baron-Fernandez 19-20). Such injustice implied the loss of an objective standard of morality; the teleology of scholastic metaphysics gave way to the contingency, relativism, and perspectivism of the modern world where force and material power settled disputes and adjudicated antagonisms.

\section{DECIPHERING EVE'S STIGMATA}

To resolve the trauma, Rizal invented female characters whose struggles sublimated his mother's experience and its painful affects. Sisa's plight may be read as Rizal's attempt to confront the violation of his mother's honor by indirection and to redress the grievance. But one apprehends an excess in the narrative, more obsessive than melodramatic, more exorbitant than the rhetorical pity and fear evoked by Aristotelian tragedy. In Chapter 21 of the Noli, the guardia civiles arrest Sisa as the "mother of thieves," blaming her for her children's actions. The mother is thus made answerable and responsible for her sons, not the delinquent father. Sisa's walk to the barracks is Rizal's re-enactment of his mother's torture, an unforgivable outrage. It was not just an empathetic re-living of the mother's agony but a mimetic performance of the ordeal. This actualization may be 
construed as a cathartic effort to assuage the compulsion to repeat the past:

Seeing herself marching between the two, she felt she could die of shame. It is true no one was in sight, but what about the breeze and the light of day? True modesty sees glances from all sides. She covered her face with her handkerchief and thus, going on blindly, she wept bitterly in humiliation. She was aware of her misery. She knew she had been abandoned by all including her own husband, but until now she had considered herself honorable and respected; until now she had regarded with compassion those women shockingly attired whom the town called the soldiers' concubines [Doña Consolacion, the alferez's wife, and Don Alberto's deviant and vindictive wife would represent this group]. Now it seemed to her that she had descended one level lower than these in the social scale. (Rizal, Noli 166)

Sisa's intense shame attests to the power of gendered socialization primarily mediated through the family and the church apparatus, as Rizal would argue in his letter to the Malolos women. But Sisa's sense of honor testifies to an inherent dignity, an impregnable self-respectqualities he recommends for Filipina women to acquire-testifying to her goodness and decency despite sordid appearances. Sisa's torment accelerates when this dweller on the fringes beyond the scope of the church bells' tolling (measuring the extent of Spanish power) approaches the town: "she was seized with terror; she looked in anguish around her: vast ricefields, a small irrigation canal, thin trees - there was not a precipice or a boulder in sight against which she could smash herself." Sisa then becomes suicidal as the urban space engulfs her. Alienated from the urban circuit of money and commodity exchange, she is terrified by the signs of civilization. Inwardly she vows to her son that they will withdraw farther into "the depths of the forest." When she reminds the soldiers that they have entered the town, Rizal's discourse becomes opaque, generalized, imposing rhetorical distance: "Her tone could not be defined. It was a lament, reproach, complaint: it was a prayer, pain, and grief, condensed into sounds" (Rizal, Noli 167). Inside the barracks, "she was convulsed with bitter sobbing - a dry sobbing that was tearless and without words." Literary artifice becomes impotent here to transcribe maternal anguish, the dissonant music of the preOedipal chora (Kristeva).

Sisa now resembles an animal, sensuous practice suspended in defensive pathos. Before she was released by the alferez who was at loggerheads with the friars, "Sisa passed two hours in a state of semi-imbecility, huddled in a corner, head hidden between her hands, hair disheveled and in disarray." She was summarily thrown out from the barracks, "almost forced out because she was too stunned to move." She is a non-entity to the alferez, a sensuous psyche consigned to the 
domain of inert objects and beasts, a figure caught in the antinomy between the transcendent and the phenomenal dimensions of human existence (Heller 229).

\section{REINCARNATIONS}

What happens subsequently is Sisa's transformation into the voice of Nature, the sentient environment of rural Philippines. Conversely, it is the humanization of the stigmatized territory customarily identified with the autochtonous ambience of savagery and barbarism, with bandits or tulisanes, with outlaws, pagans, and vagrant lunatics. With Sisa, however, Rizal describes the process of dehumanization/naturalization, beginning with her calling for her sons upon arrival at her hut, searching her surroundings: "Her eyes wandered with a sinister expression. They would brighten up now and then with a strange light; then they would darken like the skies during a stormy night. One can almost say that the light of reason was ebbing close to extinction." She wandered "screaming or howling strange sounds. Her voice had a strange quality unlike the sound produced by human vocal chords." Rizal deprives her of human language and endows her with the more infinitely varied sounds of the elements. The next day, defying the narrator's wish that "some kindly angel wing would blot out from her features and memory the ravages of suffering" and that Mother Providence would intervene during her sleep, "Sisa wandered aimlessly, smiling, singing or talking, communing with all of nature's creation," except her fellow humans.

In Rizal's poignant dramatization of this topos of pieta (mother-child linkage), Sisa commands a reservoir of psychic energy not found in the other female protagonists. It is not found in Juli, Cabesang Tales' daughter, whose labor-power had to be alienated when her father joins the outlaws. As though re-living the traumatic ordeal of Rizal's mother, the narrative voice describes Juli's walk to the convent accompanied by Sister Bali: "She thought the whole world was looking at her and pointing a finger at her." Overwhelmed with terror, she resisted Sister Bali's urging, "pale, her features contorted. Her look seemed to say that she saw death before her" (Rizal El Fili 335). Frightened by the prospect of her lover Basilio's exile, with wrath and despair, Juli closed her eyes so as not to see the abyss into which she was going to hurl herself" - the desperate assertion of her freedom, a stoic defiance of woman's enslavement.

One can infer a general tendency from this incident, a hypothetical line of argument. When the family's patriarch can no longer protect the household with the separation of the worker from the means of production/subsistence, the daughter becomes a prey for the lecherous power lurking behind the institutional enclaves and indoctrinated practices. Pushed to the extreme, Juli preserves her dignity, her chastity, in her lethal escape from that profanation emanating from the house of God's ministers. This anticipates Maria Clara's prison of Santa Clara in Intramuros at the close of 
the Noli from which the only escape is madness or enigmatic silence and disappearance enforced by the carceral discipline of an obscurantist institution. Women's experience of self is thus structured in the tension between the hegemonic ideological representations and the unfulfilled needs of the sensuous, suffering body, repressed but still animated with its genuine wants and desires.

\section{THE PATHOS OF EXCOMMUNICATING TRUTH}

In contrast to Juli, Sisa is caught in a severe contradiction: she cannot kill herself because her sons need her. The maternal instinct compels communication with other victims. In the latter part of the Noli, we encounter Sisa again on the eve of the San Diego town festival when Maria Clara and her relatives confront the leper, a blind man "singing of the romance of the fishes." Art and reality collide. The blind singer allegedly contracted leprosy by taking care of his mother. Rizal dilates on this episode of the leper who, like Sisa, uttered "strange incomprehensible sounds." When Sisa approached the leper sunk to his knees thanking Maria Clara for the spontaneous gift of her locket, what Rizal calls "a rare spectacle" dramatized here incorporates that germ of a universal principle growing out of the historically specific life-world of women in that reactionary milieu. It is the negated principle of woman's decisive function in reproduction, nurturance, and production of subsistence without which a regime of gender equality is impossible (Ebert).

This particular scene speaks volumes on the themes of justice, equality, egalitarian and participatory democracy, ecumenical peace, and ecological survival whose manifold ramifications we cannot spell out and analyze here. Notice the multilayered implications of the mad mother exhorting the blind leper to pray for the living on the day of the dead, this gesture of reconciling incompatibles deliberately punctuated by the clamor of the normal spectators to separate the two victims:

As he felt her contact, the leper cried out and jumped up. But the mad woman held on to his arm to the great horror of the bystanders, and said to him: "Let us pray! ... pray! Today is the day of the dead! Those lights are the life of men; let us pray for my sons!"

"Separate them, separate them! The mad woman will get contaminated!" the crowd was shouting, but no one dared to approach them.

"Do you see that light from the tower? That is my son Basilio who comes down by a rope! Do you see that one from the convent! That is my son Crispin, but I am not going to see them because the priest is sick and has many coins of gold and the coins got lost. Let us pray, let us pray for the soul of the priest! I brought him amargoso and 
zarzalidas; my garden was full of flowers, and I had sons. I had a garden, I was taking care of flowers and I had two sons!" (Rizal, Noli 249-50)

Of the various thematic strands and motifs woven in this network, I will only underscore three: 1) the horticultural stage of social production alluded to recalls the stage of the matrilineal/ matrilocal setup in primitive society, a time when the communal household enabled the reciprocal division of labor between the sexes - notice the absence of Sisa's husband, her sole supervision of the household, and her subsistence obtained from working the land (productive labor as one form of praxis); 2) the parasitic excess of a mercantile economy (centered on coinage extracted by friars, thus combining religious ideology and trade/commerce) monopolized by a theocratic state and a frailocracy whose mercenary use of religion demystifies their legitimacy in purveying the mystical and magical; and, finally, 3) the contamination/contagion of an alienated society, misrecognized but actually lived by the people who called for the separation of the physically diseased and the psychically abnormal, both appendages of a cancerous body politic.

We cannot help but register the behavior of the crowd as cynical, callous, and hypocritical. The spectacle manifests a further irony inscribed in the fact that the living have mortgaged their destinies to the dead-indeed, one can say that the dead fathers, tradition, fetishized rituals, idolized metals, and reifying commodities (symbolized in the Fili by the hypnotic power of Simoun's merchandise) have taken over. Aside from taxes and governmental levies on ordinary citizens, the selling of indulgences and other ceremonial fees and tributes collected by the church demonstrates systemic corruption. In the last chapter taking place on Christmas Eve, Basilio catches up with his deranged mother. Finally she recognizes him and is briefly restored to normalcy, only to die and be consumed in a funeral pyre together with the fugitive Elias. Phoenix-like, Sisa's motherhood is affirmed only to be dialectically cancelled and preserved or sublated into the predicament of other surrogates and avatars-Melchora Aquino, Salud Algabre, Felipa Culala, Maria Lorena Barros, Cherith Dayrit, Luisa Posa-Dominado, Kemberley Jul Luna, and other militants in today's national-democratic insurgency. We still labor under the sharpening crisis of the imperial fathers and their native acolytes, alarmed by the resurgent nationalism of fiery woman-warriors, mothers and daughters of a long durable and sustainable revolutionary tradition authentically of our own making (Aguilar; San Juan).

\section{EXORCISING THE “TWO-FACED GOLIATH”}

We need not linger over the semantic and philosophical complexities of other episodes where Sisa intrudes. Suffice it to mention here the scene in Chapter 40 where Doña Consolacion, 
the alferez's crazed wife tortures Sisa; or in other episodes where Sisa's seemingly gratuitous appearances at the margin of festivities disrupt the quotidian trappings and ceremonies of the respectable citizens. As an antithesis to the maternal archetype (instanced by the negative examples of Maria Clara's mother, Dona Victoriña de Espadaña, and others), Doña Consolacion may be interpreted as the wicked half of the ambiguous duality of the mythical pair Demeter/Persephone, the Laura/Flerida duality in Francisco Balagtas' awit, or Kali, the Indian goddess of fertility and destruction (Eliade 418-19). Alterity operates within the gender dichotomy, as in all socially constructed categories of subject-positions, of identities. Doña Consolacion is a modified specimen of the genre. Isolated and frustrated, forbidden from participating in the festival ("she saturated herself in her own bile") and ready to unleash repressed energies on anyone in sight. We confront again the archaic Furies hounding the perpetrators and apologists of rape and matricide.

Rizal amplifies her Medusa-like malignance in a way complementary to Sisa's unnnatural look: "Her eyes glittered like a serpent's, caught and about to be crushed underfoot. They were cold, luminous, piercing, akin to something slimy, filthy and cruel" (Rizal, Noli 346). Is this the sensitive, devout Rizal repulsed by the loathsome aspect of the sinful Eve, the mesmerizing siren and wily temptress of myth and fable? Her unrelenting brutality toward Sisa who was reduced into an animal emitting "howling sounds" can perhaps be understood as a release of dammedup resentment against her husband; but what enables her to do this is her sharing the alferez's status evident in her taunt: "Cursed be the mother who gave you birth!" With equal fury, Doña Consolacion attacks her husband, blaming him for not allowing her "to fulfill my duties toward God!" This episode is a hilarious vaudeville of marital conflict and its reverberating tensions, as evinced in the case of Uncle Alberto cited earlier. Rizal satirized local mores and manners with gusto, somewhat diverting us from the real target of the degradation of both sexes, but the power of Rizal's critique ultimately inhered in the grasp of the totality of social relations, which subsumed the economic structures that buttressed the racializing ideology and institutional practices of Spanish colonial might. What is true and real in the lived experiences of Rizal's characters (as well as his contemporaries) acquire meaning and significance only within the context of the historical totality, in the dynamic sequence of the past moving to the present and future, in nineteenthcentury Philippines.

The patriarchal age might be coming to an end, as Rizal once intoned, but its repressive legacy endured up to his death, and after. Doña Consolacion and her benign counterparts, such as Paulita Gomez and Doña Victorina, may be Rizal's strategy of thwarting feminist protest. After all, not all women conform to the Maria Clara/Leonor Rivera model. Early experiences involving Consuelo Ortigas, Leonor Valenzuela, Segunda Katigbak, the anonymous older L. of an adjacent village, not to mention the unstinting solicitude of his mother and sisters throughout his life, all 
offered Rizal comfort and affirmation of his virility in one degree or another; none threatened him or provoked an unconventional response. So whence the need to invent a nasty violent female protagonist, displaying her irrational fury and then neutralizing her by parody and caricature so as to guarantee our safety from her claims to rational judgment? Why exhibit women's aggressive capacity, her destructive potential? Why the need to exorcise the derelict, malevolent wife of uncle Alberto-if not to purge the devastating trauma of her mother's torture and compensate for the male Indio's powerlessness?

Unrequited love cannot justify any suspicion of Rizal's chauvinism. With Segunda Katigbak, it was Rizal's internal schism that paralyzed the adolescent male ego: "But at the critical moments of my life I have always acted against my heart's desire, obeying contradictory purposes and powerful doubts" (The Young Rizal 52). A schism of objective and subjective determinants erupts, signaling the subject's forced initiation into secular modernity. That crisis occurred in December 1881, six years before his engagement with Leonor Rivera was annulled by her parents who could dispose of their daughter's body without consulting her. Even though he enjoyed Nelly Boustead's company, among others, and succumbed to the O-Sei-San's insidious charm-addressing her in his diary, Rizal wrote that "No woman, like you, has ever loved me. No woman, like you, has ever sacrificed for me," not even his mother or his fiancee (Zaide and Zaide 132), Rizal confessed that he almost grew mad when he lost Leonor. It was the "first sledgehammer blow" of the railway construction that fell on him; the British engineer Kipping was a free man, Rizal was not (Quotations 113).

What was the lesson? What insight was Rizal imparting when he thwarted self-pity by proclaiming that he was not free? It was not just another male replacing him, it was a burghercitizen of the imperial metropole trouncing the Indio subaltern from the contest for a conjugal partner. It was the freedom of the modern citizen able to alienate/dispose of his/her labor-power in the anarchic market. It was ultimately industrial capitalism blasting the ethnic, geopolitical walls of empire-only to sustain the patriarchal domination of women's bodies.

Leonor Rivera died on 28 August 1893. While in exile in Dapitan, Rizal met Josephine Bracken (a Eurasian orphan from Hong Kong, Asia's burgeoning commercial center) in February 1895 with whom he fell in love. In March 1895, he wrote his mother to extend hospitality to Josephine and treat her as a person "whom I hold in great esteem and regard, and whom I should not like to see exposed and abandoned" (Guerrero 363). This "errant swallow" promised refuge from a hostile world, reviving memories of the relatively free European women whose bodies/ minds incited his imagination and fed the subterranean fountainhead of desire. She also functioned as an opportunity to re-affirm his manhood years before the time arrived when he could sacrifice his life to the object of his life's mission: decolonizing and liberating patria. 
Accompanying the estranjera Bracken, the figure of the vindictive wife (of Uncle Alberto and others) returns to the life of the Dapitan exile in the shape of his research into psychosomatic illness. On 15 November 1895, Rizal wrote the "notes for the study of Philippine medicine" entitled "The Treatment of the Bewitched" (the original title is "La Curacion de los hechizados. Apuntes hechos para el studio de la Medicina Filipina" [Quotations 138]), ostensibly a scientific account of the etiology of a disease not caused by the usual pathogenic factors.

What is striking is Rizal's description of the female witch, the manggagaway (the mangkukulam, the male counterpart, seems relatively harmless in casting enchantment), who inflicts a most mysterious, terrible illness, "though fortunately rare." The male mendicant magician is but an "involuntarily malevolent fakir," whereas the female sorcerer bewitches by suggestion. She applies "diabolical arts" the origin of which is really the social milieu, the cultural prejudices, customs, and folkways of the time. Rizal diagnoses this type of sorcery as a result of autosuggestion accompanying delirium, delirium defined by Rizal as "the lack of equilibrium between the perceptions and the conscience, a civil war inside the brain" (Miscellaneous Writings 180). This delirium is what afflicted Sisa and Juli in one degree or another. This civil war between what Freud would call the reality-principle and the pleasure-principle, between the warring forces of eros and thanatos in an Oedipalized system, acquires sociohistorical embodiment and performativity in everyday life.

Employing an objectifying stance, Rizal informs us that there are towns in Luzon where all the women enjoy the ascriptive reputation of being a manggagaway - a social phenomenon symptomatic of the entire colonial formation and its psychosomatic dynamics. The cure is immanent in its diagnosis. Here is Rizal with the physician's required detachment unable to escape pronouncing judgment on the conduct and reflex behavior of the whole society:

Although some deserve the name for their inexplicable vainglory, for their prattling, for believing that thus they make themselves terrible, nevertheless others are absolutely innocent ... A certain air, a behavior somewhat reserved and mysterious, a certain way of looking, infrequent attendance at religious services, and others, are enough to win for an unfortunate woman the reputation of manggagaway. She is the she-ass burden of ignorance and popular malevolence, the scapegoat of divine chastisements, the salvation of the perplexed quacks. Mankind also has divine defects among its divine qualities. It likes to explain everything and wash in another's blood its own impurities. The woman manggagaway is to the common man and the quack 
what the resentment of the gods, the demon, the pacts with the devil in the Medieval Age, the plethora of blood, neuroses, and others were to the different ages: She is the diagnosis of inexplicable sufferings. (Miscellaneous Writings 178)

The witch, more exactly the experience of bewitchment or possession, condenses all the tensions released from the pressures of overlapping conflicts and contradictions of a transitional phase in society, that is, a society undergoing transformative upheavals. Rizal performs the rite of the exorcising, medical shaman. Instead of inveighing and counter-cursing, Rizal's tone is elegiac, oracular, trying to discriminate and at the same time refrain from distinguishing the guilty and the innocent. Nonetheless, as a scientist-physician, he laments the human infirmity of not using reason to analyze and cure the psychic malady. Rizal anticipates Freud's transvaluation of the soul into the body-phantom registering the impingements of family/society. I submit that this discourse and its context exemplifies a memorable instance of Rizal's historical-materialist sensibility and his ethicopolitical vocation to bring about a revolution in the national psyche.

\section{ADVENT OF THE BABAYLAN}

In the course of his annotating Morga's chronicles, Rizal surely encountered the early missionaries' notes on the babaylan. His letter to Blumentritt from Dapitan (dated 20 November 1895) stated that he was "on the way to deciphering the meaning of babailan," but nothing more. What I would underscore here is a problematic silence, perhaps a tactical deference on Rizal's part (as ethnologist and physician), not to interpolate in his explanation the case of the babaylan or catalona stigmatized by the Spanish missionaries into the perverse rubric of the manggagaway.

Magic or the instrumentalization of supernatural/psychic power acquires gender differentiation in a colonially stratified milieu. Mostly widows or elderly women, the babaylans were the custodians of folk wisdom in the arts of healing, of divining the future, and the performance of propitiatory rituals. As medical practitioners, astronomers, and interpreters of culture, they exercised persuasive control over matters of reproduction and health of the community. They not only presided over the vital rituals of weddings, births, funerals, hunts, and war, they also advised the datus and sultans on how to resolve political conflicts and other problems in civic affairs. With their prestige and their authority over health, fertility, and diseases, the babaylans exhibited "the pre-condition to maximize [women's] participation and remain competitive with the men in the other spheres ... even to the extent of becoming socially equal, at times, even superior to ... the rest of society (Mangahas 13). Because these religious intermediaries are neither organized into sects nor are they in permanent contact with the supernatural realm except during trances or moments of possession, they are more precisely classified as shamanesses (Infante 194-96). 
For the historian Zeus Salazar, the babaylan functioned as the third pillar of the economic unit of the barangay, the basis for the bayan or aggregate of communal settlements, after the datu, hari, or lakan (the political head) and the panday (blacksmith). In the process of the militaryevangelical conquest of the islands, the babaylans were incorporated into church activities as religious women in charge of processions or servants of the convent. Those unable to assimilate, or who resisted the syncretizing strategy of the church, instigated and supported rebellions such as that led by Sumoroy, by Waray Tupung in Bohol, by the cofradias and various messianic organizations including the Katipunan - the formidable example of the revolutionary general Teresa Magbanua easily comes to mind, overshadowing those of Gabriela Silang or Princess Urduja (Salazar). In suppressing such revolts, the Spaniards demonized the babaylans, the custodians of the indigenous cultures, reconfiguring them as transgressive witches, manggagaways or mangkukulams (designating men who dare arrogate magical rights or privileges within the animistic frame of tribal beliefs).

It is intriguing to speculate that if Rizal was able to continue his third novel, Makamisa, or the narrative entitled “The Ancient Tagalog Nobility," we would probably have for hermeneutic inspection a full-bodied rendering of the babaylan in action. Was Teodora Alonso not one avatar of this shadowy nemesis of the patriarchal social contract? Meanwhile, we are left to ponder the vestige of calculating missionary zeal. Behind that prophylactic passage describing the female sorcerer, we witness Sisa and Doña Consolacion distilled in one phenomenal figure-the babaylan split into two embodiments. What Rizal enunciates, in general, is a symbolic complex of good and evil coexisting together, what is heretical and impious coalescing in one subject-position. Actually, it is a mirror-image of Rizal as the recalcitrant and transgressive Indio, the unpatriotic expatriate (for the friars) defying the Comision permanente de censura by speaking of the true and the real. The witch is Rizal; but the curse is this counter-statement, the doctor's report. Alienated colonial society ascribes the source of its vices, crimes, and ignorance to a fraction of the female sex and, in this collective process of purification, acquits male authority of any wrongdoing. Impartiality requires settling accounts with the patriarchs in the church and the bureaucracy.

Certain sisters of Eve functioned as scapegoat-like Christs, just as the penitent whore Magdalene came about due to "the powerful undertow of misogyny in Christianity, which associates women with the dangers and degradation of the flesh" (Warner 225; for the communistoriented views of early Christians regarding women and the family, see Kautsky 347-54), hence the whore becomes a beloved saint. In Rizal's polyvocal discourse, the realms of the sacred and profane are two halves of the same coin, one an inquiring mirror of the other; hence, the term "divine" operates here as a symptomatic rubric of the religious illusion, the ideological narcotic, that the Enlightenment and the bourgeois revolutions in Europe failed to uproot. It is now Rizal's turn 
to enlighten his women compatriots, in particular, of the need to liberate themselves from what William Blake called "mind-forged manacles" by their own collective effort and initiative. It is time to re-instate the primacy of personal autonomy and civic solidarity in the arena of everyday life.

\section{THE EPISTLE TO THE WOMEN OF MALOLOS}

Teaching and learning, for Rizal as scholar-researcher in history and ethnology, are indivisibly fused in his role as committed public intellectual (Baron-Fernandez; Ocampo). Study, collective learning, is part of emancipatory praxis that connects human agency and the ecosystem, as Marx implied in his thesis on Feuerbach: "The coincidence of the changing of circumstances and of human activity can be conceived and rationally understood only as revolutionizing practice" (Tucker 145). His now famous letter to the young women of Malolos, dated Feb. 22, 1889, was elicited by the tireless iconoclastic propagandist-rhetorician Marcelo H. Del Pilar while Rizal was preoccupied with annotating Morga's chronicles in the British Museum in London, and also answering the critics of the Noli (Ocampo). It was deliberately written in Tagalog at the time when he was also preparing his first article for the reformist journal La Solidaridad entitled "Los Agricoltores Filipinos." That intervention may be compared to Karl Marx's two contributions to the Rheinische Zeitung on the law against thefts of timber and on the destitution of the Moselle Wine Growers (McLellan 95-101).

In Rizal's inquiry into the backward conditions of the Filipino farmers, he deplored how the farmer capitalist had to battle not only floods and locusts but also petty tyrannical officials, the constable of the civil guards, and the bureaucrats of the court and the provincial government. Already equipped with an astute comprehension of the social relations of production, the political economy of the Spanish colony, Rizal this time focused his critique on the efficacy of the ideological apparatus in sustaining the unrelieved subjugation of the natives, in particular the disciplinary subalternization of women, whom he considered crucial in the formation of children's personality and disposition. In re-visiting Rizal's militant advocacy of a historical-materialist critique of society through his novels and various discourses, contra Constantino (1970) and vulgar Marxists, we can appreciate his singular contribution to humankind's libertarian archive, whatever his other limitations given the circumstances and contingencies of his personal situation and the state of the world in the latter part of the nineteenth century.

The central burden of Rizal's letter is the critique of religion, more exactly, its practice of idolatry and attendant fanaticism which violate "saintliness" defined as obedience to "the dictates of reason." Thus he bewails servitude and "blind submission to any unjust order," since each person can use a god-given reason and will to distinguish the just from the unjust. The role of the 
dissenting, inquiring conscience becomes crucial for fostering literacy and civic liberty. Positing the radical premise of all humans being born free, with no right to subjugate the will and spirit of another, Rizal urges the use of rational analysis and judgment in all activities - not just in learning Spanish, which for the Malolos women was really a pretext to have access to the mentoring wisdom of Teodoro Sandiko, Rizal's progressive compatriot, whom they wanted as teacher (the petition was eventually granted, but Sandiko was replaced by a person approved by the church).

Rizal's obsession with the need for activating the rational critical faculty is not only a rejection of the stereotypical attributes of modesty, passivity, and docility ascribed to women by custom and ecclesiastical authority, but also an attempt to include women as citizens fully qualified to participate in fashioning the "General Will" (in Rousseau's definition) of civil society. While not explicitly mentioning Rousseau, Rizal invokes reason as the primary requisite for selfmastery, for the exercise of moral liberty, which is a precondition for conceptualizing the universal interest of the whole society (Lange; Hendel). Rizal adhered to the Socratic maxim, nosce te ipsum, as conducing to the true concept of one's self which motivates the dynamic creativity of human intelligence and empowers national progress (Quotations 70). Opposing the confinement of women to devalued and debilitating reproductive labor - the expenditure of time and energy in providing nurture and socialization for dependent offspring-Rizal seeks to install women as citizens equal to men in exercising personal autonomy and sympathetic concern for others.

\section{ENCOUNTERING THE SCHOOL OF LIFE}

Rizal's judgment on colonial education in the Philippines is condensed in one sentence in his famous discourse on "the indolence of Filipinos": "The education of the Filipinos from birth until the grave is brutalizing, depressing, and anti-human" (Quotations 35). Rizal's studies in Madrid and his friendship with liberal professionals in France, Germany, and England no doubt exposed him to both Rousseau's Social Contract (1762) and Emile (1762). The latter work, Emile ou de la education, especially its fifth book, seems to be the source of general romantic ideas (which Rizal absorbed) about childhood and the importance of the constant care of the biological mother-the example of the Spartan mother Rizal cites is used by Rousseau in the first part of the book as a negative example of the perversion of natural feeling (Rousseau 8). That notion of course dovetailed with the mother-child (Virgin Mary/Jesus) family paradigm in Christian catechism. But in this context, motherhood, for Rizal, was not just a natural attribute but an achieved or acquired social role. Rizal contradicts Rousseau's dualistic belief in associating the female with body/nature/family and the male with mind/citizen/public life. His radical egalitarianism springs from his desire to enroll Filipino women into the ranks of anti-Spanish colonial partisans of the national struggle. 
Social expectations, not just the family-imposed sexual division of labor, defined the mother as a redemptive teacher.

What is lamentable, for Rizal, is the Filipino woman's failure to be good mothers due to their profligate addiction to gambling, their subservience to the mercenary friars, their zealotry in conforming to reified rituals, and their complacent ignorance: "What sons will she have but acolytes, priest's servants, or cockfighters?" Sisa's gambling husband and her two sons in the convent loom in the background. In suggesting that mothers replace the friars as the fountainhead of moral guidance in the family, Rizal valorizes the agency of mothers as educative/formative forces primarily responsible for shaping the character of their children: "you are the first to influence the consciousness of man.... Awaken and prepare the will of our children towards all that is honorable, judged by proper standards, to all that is sincere and firm of purpose, clear judgment, clear procedure, honesty in act and deed, love for the fellowman and respect for God" (Zaide and Zaide 327).

Lacking civic organizations outside the family, the mother then becomes the only viable pedagogical alternative to the convent and the church-regulated schools. The native fathers are either conscripted by the government for military service, for unpaid public labor, or occupied in cultivating friar-owned lands. Rizal affirms his faith in the power and good judgment of Filipino women. He believes that Asia is backward because Asian women are ignorant and slavish, whereas in Europe and America "the women are free and well educated and endowed with lucid intellect and a strong will" (Zaide and Zaide 128). We know that Rizal admired German women who "are active and somewhat masculine," not afraid of men, "more concerned with the substance than with appearances" (letter to Trinidad Rizal, 11 March 1886, in Letters 223). The figure of Teodora Alonso, the moralizing mother-teacher, is not far behind.

\section{EXCURSION TO SPARTA}

It is therefore not surprising that Rizal would invoke the civic conscience of Spartan mothers as exemplary. We should first grasp the truth of our situation, he reminds his Malolos audience, perhaps deducing lessons from his own experience: young students lose their reason when they fall in love, and so beware. The passions mislead (to use Spinoza's terms); adequate knowledge of nature is needed to act wisely and responsibly. Moreover, marriage makes shameless cowards of the bravest youth. Rizal then advises women who are married to "aid her husband, inspire him with courage, share his perils, refrain from causing him worry and sweeten his moments of affliction ... Open your children's eyes so that they may jealously guard their honor, love their 
fellowmen and their native land, and do their duty," like the women of Sparta (Zaide and Zaide 330). Rizal extolled Spartan women for giving birth to men who would willingly sacrifice their lives in defense of their homeland.

But Rizal did not mention how that practice was possible because of the rigorous militaristic regimen imposed on the training of Spartan youth, the rigorous routine of the agelai or herds (described by Plutarch) in disciplining youth solely for fighting. Ruled by an exclusive ruling caste, Sparta suppressed their serfs (helots) with a permanent military organization (a standing army) and a tribal system of common ownership that prevented the disruptive effects of commodity production, industry, and trade using coinage (Thomson, The First Philosophers 210-11). The Spartan oligarchy administered the polity's settlement (family estates with serfs) as the prime economic unit based on communal ownership of the soil and local handicrafts. Spartan women were also trained in the agelai but "they were free to go about in public; adultery was not punishable or even discreditable; a woman might have several husbands" (Thomson, Aeschylus 190). We are still in a quasi-primitive communal society (somewhat similar to pre-conquest Philippines) where women's work extended beyond the private household. In supervising the production of subsistence and other use-valued goods, women exercised a measure of power and effective rights in the public sphere.

It is clear that Spartan mothers were not the educators Rizal conceived them to be. They did not raise their sons who, at the age of seven, were enrolled in the agelai and transferred to the Men's House at nineteen, devoting themselves to military exercises. When married, Spartan men did not live with their wives but visited them clandestinely on occasions; the brides/wives lived with their parents. Women obtained substantial dowries and inherited two-fifths of the land in the absence of their husbands; though excluded from political life, their indispensable position as heiresses and managers of the estates with their ubiquitous helot labor gave them so great an influence that Aristotle spoke of Sparta as a country "ruled by women" (Thomson, Aeschylus 192). Because of the division of labor between the sexes, all adult males served in the standing army while the women administered the family estates. This is what allowed Spartan mothers to sternly judge the performance of their soldier-sons, not their care or nurturance in the private domain of the fathercentered home, as Rizal seemed to believe. Education was in the hands of the patriarchal oligarchy of Sparta, not in those of mothers or daughters.

One would expect Rizal to be more knowledgeable or informed, but surely a full substantial description of Spartan society was not his intention. His purpose was to praise Spartan unity about 9,000 citizens "economically self-sufficient and politically enfranchised" (Anderson 35) - and their selfless devotion to the defense of their homeland originally conquered from the indigenous Messenians who became state helots. The austere independence of Spartan women thrilled Rizal. In 
his 1886 letter to his sister Trinidad, Rizal objected to the Filipino women's obsession with clothing and finery attuned to the demands of the marriage market. His instructions at the end reiterate the fundamental virtues of courage, diligence, dignity, and personal autonomy derived from acquiring knowledge ("ignorance is servitude") and the cultivation of intellect, as well as the fulfillment of reciprocal obligations toward others. This repeated exhortation to cooperation and mutual help, a pre-requisite in forging national sentiment (Majul 73-185), precedes the somewhat peremptory fifth injunction: “If the Filipina will not change her mode of being, let her rear no more children, let her merely give birth to them. She must cease to be the mistress of the home, otherwise she will unconsciously betray husband, child, native land, and all." Beware, parents of Leonor Rivera, Segunda Katigbak, and their sisters - you may be nurturing treacherous wives who pretend to be "mistress of the home" while scheming to deliver husbands, children, homeland, to the enemy. Rizal's parting words seem even more rebarbative: "may you in the garden of learning gather not bitter but choice fruit, looking well before you eat because on the surface of the globe all is deceit and the enemy sow seeds in your seedling plot."

\section{EXPERIMENTAL REALISM}

In spite of such shortcomings, the sixth instruction in Rizal's epistle sums up his pedagogical creed: to value intelligence and reason as the enabling principle of equality and solidarity with others. What is reasonable and just is the aim of learning; "to make use of reason in all things" entails the rejection of egotism and the local barbarism of folklore, superstitions, fossilized notions, and anachronistic habits that prevent Filipinos, men and women, from reflecting on their common situation and critically analyzing the impact of movement and change in their collective life. One can detect in Rizal's emphasis on using the "sieve of reason," which is mobilized to grasp "the truth of the situation," an over-anxious insistence in developing civic consciousness in women, expressed here as praise for their "power and good judgment," "fortitude of mind and loftiness of purpose," and so on. Here Rizal departs from Rousseau's maxim of differential worth, as well as from the commensical, biologistic, liberal notions of the sexes complementing and/or supplementing each other, in treating women as equal to men in being capable of reflective self-development and civic agency in the public sphere. Nonetheless, he subscribes to the French revolution's ideals of equality, liberty, and fraternity refracted through the prism of deistic Christianity, "religion within the bounds of practical reason," in Kant's phrase; and of communal honor, Rizal's "self-esteem," in riposte to Fr. Pastell's sardonic attitude (Palma 235-47).

Anxious to defend women's honor maligned by the friars and abusive Spanish visitors, Rizal can only retort that Spanish women themselves are not all "cut after the pattern of the Holy 
Virgin Mary." Since the Malolos women for the most part belonged to the ilustrado/principalia class comprised of families with bilateral extensions, Rizal can only abstractly valorize rationality as crystallized in the concrete practice of nurturing children. The household realm is open to affinitive reconstruction. The everyday life becomes a domain of paramount concern. In the process, he appraises women's work in the household as one mediating the relations of the natural and social orders. This domestic work generates what Antonio Gramsci calls "the first elements of an intuition of the world free from all magic and superstition" "In Search" 52). Learning, education as the internalized absorption of modalities of empirical investigation and synthetic-analytic reflection, follows Rizal's insight (written from Barcelona circa 1881) that "the knowledge of a thing prepares for its control. Knowledge is power" (Quotations 70).

Unlike Sisa, Juli, Salome, and women of the peasantry and village artisans, the Malolos assemblage-Rizal surmises - is struggling to overcome the bondage of limited schooling and constricted participation in civic affairs due mainly to the consensual routine of stultifying religious indoctrination. In addition, one has to reckon with paternal surveillance and the long tradition of the pasyon and its focus on the mystical transcendence of human suffering. The petition submitted to Gov. Valeriano Weyler to open a night school so that young women might learn Spanish under the progressive mentor Teodoro Sandiko served as the first step in breaking down that bondage of silence and the customary acceptance of women's inferiorization. Their spontaneous agitation may be conceived as their recognition of "necessity" as freedom when they reached out to the propagandists in Madrid and outside their province, a strategic move embodying the radical principle of socializing what was deemed natural and historicizing what was deemed immutable, fated, or predestined. Modernity's historicizing drive has taken over Malolos and the embryonic Filipino diaspora.

\section{ILUSTRADO HUBRIS}

In the letter, Rizal refined and complicated the analysis of the political economy underlying Filipino women's circumscribed lot to a critique of the church-induced habitus (Bourdieu) of submission and self-abnegation. The reason for this is that in the colonial setup, the ideological propaganda apparatus of the church and its capillary agencies predominated over any liberal reformist tendencies of the arbitrary secular-civilian administration. We can appreciate this better if we keep in mind the ethos of unquestioning obedience and decorum prescribed for women by normative codes and institutional practices distilled, for example, in Lagda (1734), a manual of exemplary Christian conduct, and in the widely read text of Father Modesto de Castro, Urbana at Felisa (1864), self-described as "an educational moral novel" (Mojares 82). 
The historian Maria Luisa Camagay remarks how the frailocracy abused its authority by sexually exploiting women workers, particularly those applying for the position of maestra (teacher) and matrona (midwife): "The friar proved to be a bane in the life of Filipino women in the $19^{\text {th }}$ century" (Working Women 121). With the employment of more women into the flourishing tobacco factories and in paid domestic services, the power of the frailocracy was gradually demarcated and focused on the women of the principalia (e.g., Pia Alba, Maria Clara). It was inflicted on the twentyone Malolos women, entrepreneurs in farms and urban businesses, who wanted to use part of their free night-hours to develop their intellects and acquire urbane skills.

Rizal was also aware of the enormous weight of Spanish colonial laws-for example, the Spanish Marriage Law of 1870 - that subordinated women to the property-owning husband. Applying the doctrine of Roman jurisprudence concerning patria postestas with the male paterfamilias as absolute ruler, this law together with other Royal Decrees segregated women into colegios and beaterios that prepared women either for motherhood or the religious life (Feliciano). Rizal's antiauthoritarianism targeted the gendering mechanism of schools, court and bureaucracy, even though by 1781 women were being hired by government-owned tobacco factories, and by 1894 they were being admitted to teaching careers (Camagay, "Women Through Philippine History" 35). Such recruitment into waged labor in fact simply substituted market compulsion for paternal/ church authority. Rizal's praise of prudent resistance to authority, balanced with his stress on "justice [as] the foremost virtue of civilized nations" (in "The Philippines a Century Hence"), distinguishes his implied philosophy of education as part of his agonistic, but also perspectival and thoroughly modern, view of life conveyed to his nephew during his Dapitan exile:

To live is to be among humans and to be among humans is to struggle. But this struggle is not a brutal and material struggle with men alone; it is a struggle with them, with one's self, with their passions and one's own, with errors and preoccupations. It is an eternal struggle with a smile on the lips and tears in the heart. On this battlefield man has no better weapon than his intelligence, no other force but his heart. Sharpen, perfect, polish then your mind and fortify and educate your heart. (Letters 375)

Self-discipline as Enlightenment desideratum was also what he was trying to articulate in the letter, except that he was more preoccupied with altering the psychophysical disposition of women inured to passivity, obedience, and silence, which over-determined the fates of Maria Clara, Juli, and Sisa. This accounts for the emphasis on a militarized sense of corporate honor, a warrior ethos distinguished by an ascetic regimen in fulfilling duty and obligations to the community, as 
if he was trying to convert the feminine habitus to a more competitive, adversarial mode (on the ethos of honor, see Ossowska). It seems as though the entrepreneurial Rizal, who engaged in the abaca trade, complained of not earning enough as an eye-doctor, and gambled in the lottery, was more preoccupied with inculcating the aristocratic virtues of the feudal nobility than the bourgeois ethos of regularity, thrift, and profit-motivated cunning. The Spartan model haunts the margins of the epistolary script. He was skipping the stage of hypocritical merchant capitalism (identified with a mercenary priesthood and parasitic native bureaucracy) in favor of a utopian meritocratic arrangement allowing the intelligent an iota of elite privilege while maintaining a semblance of aristocratic decorum.

Although marginal to the plot of the Noli (in fact, the whole chapter "Elias and Salome" was excised from the final version), the character Salome displays more affinities with her Malolos sisters, given her relative control over her means of subsistence and her isolation. She is the remaindered kin of the ostracized babaylans. With Elias' decision not to marry her in order to spare her the misery of a wretched family life, she plans to move to the frontier land of Mindoro and join her relatives. Living happily in the wilderness, desiring nothing but health to work and enjoy what is freely offered, not envying the rich girls their wealth, Salome anticipates the nature deity Maria Makiling of Rizal's reconstituted folklore, the patria of the exiled hero.

Salome implores the fugitive Elias to use her dwelling: "It will make you remember me ... When my thoughts go back to these shores, the memory of you and that of my home will present themselves together. Sleep here where I have slept and dreamed ... it would be as if I myself were living with you, as if I were at your side" (Noli 216-17). The narrative conjures their consensual togetherness, their carnal liaisons, their mutual belonging, in fantasy or compensatory wishfulfillment that is invariably women's mode of transcending quotidian misfortunes. What imbues space with charismatic import and historic significance is women's work, affection, care; hence Rizal's extreme anguish that mothers perform their nurturing, child-rearing task well in fashioning autonomous citizens. Natural law takes precedence over positive man-made laws.

\section{ENVISIONING THE TOTALITY}

On December 31, 1891, shortly after completing the Fili, Rizal wrote to Blumentritt that the reformist La Solidaridad is no longer his chosen battlefield. With the sharpening crisis of the Spanish empire, the arena has shifted to the Philippines (Zaide and Zaide 213). His family had suffered an irreversible catastrophe when they were evicted by the Dominican friars from the Calamba hacienda the year before and his relatives persecuted. His sojourn in Hong Kong marks his definitive turn to an insurrectionary, separatist solution for the colony. 
His two epistolary political testaments dated 20 June 1892, and his founding of the Liga Filipina on his arrival in Manila in June-July 1892, herald the beginning of Sisa's and Juli's "vengeance," a recovery of the primal outrage. Melancholia's shroud may have fallen on Rizal in Dapitan, but underneath it all the victims of colonial tyranny are gathering for a coven/covenant to exorcise the demonic plague. Rizal's own view of the synoptic, ruminatory years of his Dapitan exile may be discerned in the "structure of feeling" (Williams) behind his statement to Fr. Pablo Pastells: "I am at present at the enactment of my own work and taking part in it" ("Rizal to Blumentritt" 63). The present fuses the past and future in one intuitive act of Rizal's sensibility, his personal judgment of the totality of his experience universalized by sharing its moral import with others capable of empathy, reciprocity, or vicarious identification with neighbors and fellow protagonists. Modernity, characterized by the hegemony of capitalist norms, revisits like a vampire the archaic layers of the communal past since it cannot answer objectively the inescapable ethicopolitical and essentially moral questions of what is true justice, virtue, and the good life from a global/cosmopolitan perspective (Gramsci, Selections).

A more historicized appraisal of Rizal in this age of terrorism would thus move the center of inquiry to the Dapitan years following the Hong Kong interlude, the contacts with the plebeian/ proletarian strata interested in the Liga, and the Liga's resonance (Olsen). It is the moment of timely reckoning. By exposing the limits of Simoun's anarcho-utopian idealism and Padre Florentino's eschatological wish-fulfillment, Rizal moved to engage in its existential ramifications the SisaSalome nexus embedded in the carnivalesque world of colonial Philippines deprived of any nomos or transcendental authority. Rizal anticipates the postmodern predicament of the dissolution of a meaningful world in vacuous finance-capitalism.

Women's vengeance against patriarchal nihilism lies submerged in Rizal's communicative gesture to the Malolos contingent, potential cadres or partisans of the nascent Katipunan-led revolution. This outreach mobilizes emergent and residual historical forces in a dialectical trajectory of canceling the negative (mystifying ideologies and practices) and salvaging the mother's body/ place as the site of the subject's reconstitution. This itinerary of changes in his thinking provides a seismographic organon for comprehending Rizal's radical critique, his theory of transforming patria and the regenerative delirium of its victims into a counterhegemonic historic bloc (Quibuyen), the matrix of all subversive insurgencies. This will permanently nullify the common prejudice that Rizal should be dismissed as an American-installed icon and replaced by the actiondriven Bonifacio, thereby unwittingly admitting pragmatic expediency and a cultic voluntarist spontaneism as the criteria of populist hero-worship.

We can sidetrack Simoun's conspiracy in the Fili and focus instead on a utopian moment in Rizal's narrative. By this I do not mean the utopian-socialist trend of Saint Simoun, Fourier and 
Owen criticized by Engels in Socialism: Utopian and Scientific (published in French 1880, with English translation in 1892). While Rizal may have absorbed ideas surrounding the debates around both Engel's polemic and the earlier 1848 Communist Manifesto, his general philosophical outlook owes its bearings more to the classical Greek and Roman tradition inflected by Cicero, Duns Scotus, and Thomas Aquinas, then subsequently re-oriented by the secularizing Renaissance and by the Enlightenment (Voltaire, Diderot, Rousseau); and radicalized later by such mavericks as the Marquis de Condorcet, the theoreticians of the Paris Commune of 1871, William Godwin, and Mary Wollstonecraft-see, in particular, her A Vindication of the Rights of Woman issued in 1792 (Mitchell 68-72; Beauvoir 136-37).

In his commentary on Morga's Sucesos, Rizal's vindication of Filipino women's honor (reiterated in the Malolos epistle) finds eloquent testimony. It is a return to the past before mother-right was completely annulled, when the self-sustaining security of the gens (clan) had not completely yielded to the vulnerable, isolated nuclear family dominated by the propertyowning male. Women still participated in socially necessary labor (Sisa's horticultural knowledge is a survival) in the domestication of crops and household management, before the complete dehumanization of mother-oriented communal ties in the subjugated colony. Because Filipina women are not a burden to the husband, Rizal argues, she does not carry a dowry: "the husband does not take a heavy burden or the matrimonial yoke, but a companion to help him and to introduce thrift in the irregular life of a bachelor" (Quotations 26). Even though the native woman before the Spanish conquest "represents a value for whose loss the possessor [parents] must be compensated, she was never a burden on her parents or husband; European families, however, seem to be in a hurry to get rid of their marriageable daughters, with mothers frequently playing a ridiculous role in the sale of her daughter." The sale and purchase of Filipino women is not a custom in the past, according to Rizal's ethnological research (but there are widespread exceptions, as documented by Teresita Infante):

The Tagalog wife is free and respected, she manages and contracts, almost always with the husband's approval, who consults her about all his acts. She is the keeper of the money, she educates the children, half of whom belongs to her. She is not a Chinese woman or a Muslim slave who is bought sometimes from the parents, sometimes at the bazaar, in order to lock her up for the pleasure of the husband or master. She is not the European woman who marries, purchases the husband's liberty, initiative, her true dominion being limited to reign over the salon, to entertain guests, and to sit at the right of her husband. (Quotations 26) 
Allowing for a certain overstatement in the position of women in pre-colonial times, it is accurate to state that in the communal stage of the barangay, the division of socially necessary labor and with it, the specification of gender roles, had not yet been affected by commodity production and the circulation of exchange values. To the degree that women participate integrally in productive work, as well as with the reproductive labor of the household, they enjoy a measure of equality with men. As soon as private property (land, labor, commodities) becomes the dominant logic of the social order, male supremacy and monogamy prevail, supplemented by adultery and prostitution (Leacock). When women were excluded from productive work and confined to kitchen and boudoir, their participation in political and public affairs also ended. With the male partner absent or emasculated, Sisa and Salome enjoyed a latitude of activity, a degree of autonomy, not shared by Maria Clara, Paulita Gomez, or Leonor Rivera.

We may hypothesize that this is one of the reasons why Rizal found Josephine Bracken, whom he celebrated in his "ultimo adios" as "dulce extranjera," a breath of fresh air. It was a temporary respite from the surveillance of the solicitous mother and his female siblings. Even though she was obedient, meek, and did not answer back when Rizal lectured, she belonged to the European/Western "race" and was not averse to engaging in manual labor in Dapitan. Clearly, Rizal was not threatened by her, as he was by Nelly Boustead, Gertrude Beckett, or the businessminded Viennese temptress; she was an orphan, with "nobody else in the world but me [Rizal]" (Letters 417). Despite appearances, she harbored an excess beyond his control. In the hours before his death, Rizal wrote his family, asking forgiveness and requesting them to "Have pity on poor Josephine" (Letters 439). After her marriage to Rizal and his execution, Bracken actively participated in the revolutionary war led by General Emilio Aguinaldo (Ofilada), perhaps realizing a fragment of Rizal's image of those formidable Spartan mothers he invoked as guides to the promised land

\section{INTERVENTION FROM THE MOUNTAIN: A MILLENARIAN PROJECT?}

Whatever the impasse of contradictions undermined his life, Rizal never gave up amor patria, the "most heroic and most sublime human sentiment." He celebrated this obsessive nostalgia for the homeland in his first propagandist contribution to Diariong Tagalog (20 August 1982) when he landed in Barcelona on his first sojourn in Europe. Rizal is rhapsodic in proclaiming his adoration for the Motherland which inheres in every human: "She has been the universal cry of peace, of love, and of glory, because she is in the hearts and minds of all men, and like the light enclosed in limpid crystal, she goes forth in the form of the most intense splendor" (Miscellaneous Writings 15). She is incarnate in fantasy, in the mythical figures associated with the natural surroundings, with the soil and rivers of the native land: "And how strange! The poorer and more wretched she is, the more 
one is willing to suffer for her, the more she is adored, the more one finds pleasure in bearing up with her "(Miscellaneous Writings 16).

Geographical space, the occupied territory, becomes a concrete, lived place; it mutates into a libidinally charged locus of pleasure and self-sacrifice. When the motherland is in danger, the more intense the desire to come to her aid; the motherland symbolizes all those kin you have lost, the fountainhead of dreams, but also where "true Christianity" abides. Rizal finally identifies what he would later address, in his farewell poem, "mi patria idolatrada, dolor de mis dolores/Querida Filipinas," with Christ "on the night of his sorrow." Our sacrifices will revive the dying, suffering homeland (in the martyr's allegorical rendering), now taking the persona of Josephine Bracken"mi amiga, mi alegria" - now that of Maria Makiling and her eternally recurrent metamorphosis. This is the antithesis to the imperial masculinist high-bourgeois nationalism of the oppressor metropoles so lustily condemned by arrogant pundits and academic stars of the global North, selfaggrandizing sophists so proud of their erudition and their always infallible opinions on what's wrong with the world.

It is instructive that Rizal, instead of dwelling on the didactic fable of Malakas and Maganda (co-opted by the hired publicists of the Marcos dictatorship 1972-1986) born together as a sign of gender parity, calls our attention to the legend of Maria Makiling. She concentrates in her figure the diverse manifestations of the nature-fertility goddess throughout the archipelago. While inhabiting the borderline between nature and civilization, she remained a virgin, "simple and mysterious like the spirit of the mountain." Initially, she favored humans with her grace and bountiful beauty; but when she was deceived by her earthly lover, she took revenge. Rizal suggests that perhaps she was infuriated by the attempt of the Dominican friars "to strip her of her domains, appropriating half of the mountain" (Miscellaneous Writings 107). The goddess rebuked her human lover when he took another bride: "inasmuch as you had not courage either to face a hard lot to defend your liberty and make yourself independent in the bosom of these mountains; inasmuch as you have no confidence in me, I who would have protected you and your parents, go; I deliver you to your fate." Since then, the goddess never again showed herself to humans, no matter how hard they searched for her "along the famous ascent that the friars called filibustera," according to Rizal. The original harmony of humans and the ecosystem is sundered by predatory acquisitiveness, by the exploitation of nature to yield subsistence, so "neither the enchanted palace nor the humble hut of Mariang Makiling could be glimpsed" again (Miscellaneous Writings 110).

And so did Salome abandon her home in the forest, so did Sisa and Juli depart from the fallen world of Padre Camorra, Padre Damaso, and Padre Salvi, of Doña Consolacion, the alferez and guardia civiles - the outposts of the crumbling Spanish empire. In the 1892 Hong Kong letter, he declared: "I desire, furthermore, to let those who deny our patriotism see that we know how to 
die for our duty and for our convictions. What matters death if one dies for what is loved, for the country, and for the beings that are adored?" (Palma 351). Rizal is sacrificing himself on the temple steps, a programmatic gesture inaugurated in the Noli's preface. Sisa's vengeance arrives here with the martyr's apostrophe to the Motherland to pray for "our unhappy mothers who in bitter sorrow cried," rendering judgment on those condemned to languish in a world where slaves bow before the oppressor, where faith kills. At the end of his 1884 eulogy to the painters Juan Luna and Felix Resurrecion Hidalgo, Rizal offered a paean to Filipino parents after delivering a challenge to their children: "The furrow is ready and the ground is not sterile!" (Zaide and Zaide 74).

\section{WHAT IS TO BE DONE?}

It was in the same year, 1884, when Rizal became involved in the university student insurrection in Madrid, that Engels' epoch-making book, The Origin of the Family, Private Property and the State, was published. In mapping the evolution of the family, Engels noted that Spartan women occupied a much more honored position and exercised greater sexual freedom than anywhere else in antiquity during that period. This was because pairing marriage, not monogamy, was still practiced in Sparta; private property of land and household goods was unknown. Like Rizal, however, Marx and Engels to a lesser degree were still deeply "imbued with the rationalist tradition of Plato and More to allow free play to all psychosexual desires as authentic needs" in the way Charles Fourier (or the Marquis de Sade) did in his utopia of amorous "passionate refinement" (Manuel and Manuel 710). Before and during his first sojourn in Spain in 1882-85, Rizal had already digested Rousseau, Voltaire, Schiller, and Victor Hugo, but not Fourier. To be sure, he knew the Russian Nihilist movement and probably Proudhon and Bakunin, and indirectly Marx and Engels, given the contentious ambience of anarchists, syndicalists, and utopian socialists saturating Paris, London, Brussels, Berlin, Vienna, and other cities he visited from 1886 to 1887, and later from 1888 to 1892. In this context, Rizal might plausibly be called the first Filipino high modernist during the twilight of the Spanish empire.

Four years before his death, Rizal responded to his Jesuit "inquisitor" Fr. Pastells: "My sole wish is to do what is possible, what is in my hands, the most necessary. I have glimpsed a little light and I believe that it is my duty to teach it to my countrymen" (Quotations 93). In being fully comprehended and assayed, the realm of necessity, of fate, becomes the terrain of freedom; thus, as he earlier observed in "The Philippines a Century Hence," "every country meets the fate that she deserves." Whether we deserve Rizal and the ideals he fought for is a question whose answer may already be immanent in the ongoing struggles in the open green fields around us. Uncannily serendipitous, inhabiting the borderland between patriarchy and matrilineality, the surname 
San Juan

Sisa's Vengeance

"Rizal" is not found in the clan genealogy. The patronymic "Rizal" was given by an unnamed provincial governor to distinguish the dangerous Mercados of Calamba, a gratuitous addition that fulfilled in the ripeness of time its prophetic signification in designating "a field where wheat, cut while still green, sprouts again" (Guerrero 19). 


\section{WORKS CITED}

Aguilar, Delia. Toward a Nationalist Feminism. Quezon City: Giraffe, 1999.

Anderson, Perry. Passages from Antiquity to Feudalism. New York: Verso, 1974.

Arcilla, Jose. Rizal and the Emergence of the Filipino Nation. Quezon City: Ateneo de Manila UP, 1991.

Baron-Fernandez, Jose. Jose Rizal: Filipino Doctor and Patriot. Quezon City: Manuel Morato, 1980.

Beauvoir, Simone de. The Second Sex. New York: Vintage, 1952.

Bourdieu, Pierre. Outline of a Theory of Practice. London: Cambridge UP, 1977.

Camagay, Ma. Luisa. "Women Through Philippine History." The Filipino Woman in Focus. Ed. Amaryllis

Torres. Bangkok, Thailand: UNESCO, 1989.

-. Working Women of Manila in the 19 $9^{\text {th }}$ Century. Quezon City: U of the Philippines P, 1995.

Caudwell, Christopher. Studies and Further Studies in a Dying Culture. New York: Monthly Review Press, 1971.

Constantino, Renato. Dissent and Counter-Consciousness. Quezon City: Malaya, 1970.

Craig, Austin. Lineage, Life and Labors of Jose Rizal. Manila: Philippine Education Co., 1913.

Ebert, Teresa. Ludic Feminism and After. Ann Arbor, MI: U of Michigan P, 1996.

Eliade, Mircea. Patterns in Comparative Religion. New York: Meridian, 1958.

Engels, Friedrich. The Origin of the Family, Private Property and the State. New York: International Publishers, 1972.

Eviota, Elizabeth Uy. The Political Economy of Gender. London: Zed, 1992.

Feliciano, Myrna. “The Filipina: A Historical Legal Perspective.” Women's Role in Philippine History: Selected Essays. Quezon City: University Center for Women's Studies, 1996.

Feria, Dolores. "The Insurrecta and the Colegiala." Rizal: Contrary Essays. Eds. Petronilo Bn. Daroy and

Dolores Feria. Quezon City: Guro, 1968.

Goody, Jack. Food and Love. London: Verso, 1998.

Gramsci, Antonio. "From 'In Search of the Educational Principle'." Studies in Socialist Pedagogy. Ed. Theodor Mills Norton and Bertell Ollman. New York: Monthly Review Press, 1978.

-. Selections from Cultural Writings. Ed. David Forgacs and Geoffrey Nowell-Smith. Trans. William

Boelhower. Cambridge, MA: Harvard UP, 1985.

Guerrero, Leon Maria. The First Filipino: A Biography of Jose Rizal. Manila: Vertex, 1969.

Gurvitch, Georges. The Social Frameworks of Knowledge. New York: Harper Torchbooks, 1971.

Hays, H.R. From Ape to Angel. New York: Capricorn, 1958.

Heller, Agnes. A Theory of Modernity. New York: Blackwell, 1999.

Hendel, Charles W. Jean-Jacques Rousseau: Moralist. New York: Bobbs-Merrill, 1934.

Infante, Teresita R. The Woman in Early Philippines and Among the Cultural Minorities. Manila: Unitas, 1975.

Joaquin, Nick. “Small Beer: Love Scene.” Philippine Daily Inquirer 13 Feb. 1988: 11.

Kautsky, Karl. Foundations of Christianity. New York: International Publishers, 1925.

Kristeva, Julia. The Kristeva Reader. New York: Columbia UP, 1986.

Lange, Lynda. "Rousseau: Women and the General Will." The Sexism of Social And Political Theory. Ed. Lorenne

Clark and Lynda Lange. Toronto: U of Toronto P, 1979.

Leacock, Eleanor B. "Introduction." The Origin of the Family, Private Property and the State. By Friedrich Engels.

New York: International Publishers, 1972. 
Lopez, Salvador P. “Maria Clara-Paragon or Caricature?” Rizal: Contrary Essays. Eds. Petronilo Bn. Daroy and Dolores Feria. Quezon City: Guro, 1968. 81-84.

McLellan, David. Marx Before Marxism. New York: Harper and Row, 1970.

Mangahas, Fe. "From Babaylan to Suffragettes: The Status of Filipino Women from Pre-Colonial Times to the Early American Period." Kamalayan: Feminist Writings in the Philippines. Ed. Pennie Azarcon. Quezon City: Pilipina, 1987.

Manuel, Frank, and Fritzie Manuel. Utopian Thought in the Western World. Cambridge, MA: Harvard UP, 1979. Majul, Cesar A. “On the Concept of National Community." International Congress on Rizal. Manila: Jose Rizal National Centennial Commission, 1961.

Marx, Karl, and Friedrich Engels. The Marx-Engels Reader. Ed. Robert Tucker. New York: Norton, 1978. Mitchell, Juliet. Women: The Lost Revolution. New York: Pantheon, 1984.

Mojares, Resil. Origins and Rise of the Filipino Novel. Quezon City: U of the Philippines P, 1983.

Nakpil, Carmen Guerrero. “The Filipino Woman.” 1952. Asian and Pacific Quarterly XII.2 (1980): 10-18.

Ocampo, Ambeth. "Rizal's Morga and Views of Philippine History." Philippine Studies 46.2 (1998): 184-214.

Ofilada, Macario. Errante Golondrina. Quezon City: New Day, 2003.

Oizerman, T. I. The Making of the Marxist Philosophy. Moscow: Progress, 1981.

Olsen, Rosalinda N. "Rizal and the Myth of the Golden Pancake." Bulatlat 7.5. 4-10 Mar 2007.

Ossowska, Maria. Social Determinants of Moral Ideas. Philadelphia: U of Pennsylvania P, 1970.

Palma, Rafael. The Pride of the Malay Race. New York: Prentice Hall, 1949.

Quibuyen, Floro. A Nation Aborted. Quezon City: Ateneo de Manila UP, 1999.

Rizal, Jose. El Filibusterismo. 1891. Trans. Soledad Lacson-Locsin. Manila, Philippines: Bookmark, 2004.

-. Letters Between Rizal and Family Members 1876-1896. Manila: National Historical Institute, 1993.

-. Miscellaneous Writings of Dr. Jose Rizal. Vol. 8. Manila: National Heroes Commission, 1964.

-. Noli Me Tangere. 1887. Trans. Soledad Lacson-Locsin. Manila: Bookmark, 2004.

-. Quotations from Rizal's Writings. Trans. Encarnacion Alzona. Manila: National Historical Institute, 1999.

-. "Rizal to Blumentritt, London, Nov. 8, 1888." Epistolario Rizalino. Vol. 5, Part 1. Ed. Teodoro M. Kalaw.

Manila: Bureau of Printing, 1938.

-. The Young Rizal. Trans. Leon Ma. Guerrero. Manila: Bardavon, 1950.

Rousseau, Jean-Jacques. Emile. Trans. B. Foxley. New York: Macmillan, 1969.

Salazar, Zeus. Women's Role in Philippine History: Selected Essays. Quezon City: University Center for Women's Studies, 1996.

San Juan, E. Filipina Insurgency. Quezon City: Giraffe, 1999.

Thomson, George. The First Philosophers. London: Lawrence and Wishart, 1955.

-. Aeschylus and Athens. New York: Universal Library, 1968.

Tucker, Robert C. The Marx-Engels Reader. New York: Norton, 1972.

Warner, Marina. Alone of All Her Sex: The Myth and Cult of the Virgin Mary. New York: Vintage, 1976.

Williams, Raymond. Marxism and Literature. New York: Oxford UP, 1977.

Zaide, Gregorio, and Sonia Zaide. Jose Rizal: Life, Works and Writings of a Genius, Writer, Scientist and National Hero. Manila: National Bookstore, 1984. 